\title{
The Journal of Laryngology and Otology
}


Printed in Great Britain by Headley Brothers Ltd The Invicta Press Ashford Kent and London 


\section{The Journal of Laryngology and Otology}

E D IT E D B Y

JOHN BALLANTYNE

ASSISTANT EDITORS

DAVID WRIGHT\& JOHN BOOTH

ADVISER IN PATHOLOGY

PROFESSOR I. FRIEDMANN

FOUNDED IN 1887 BY MORELL MACKENZIE AND

NORRIS WOLFENDEN

VOLUME ONE HUNDRED AND ONE

Published for the Proprietors by

HEADLEY BROTHERS LTD

Ashford, Kent TN24 8HH

1987 
771 